\title{
Fossil remains of proterosuchian from the Panchet Formation, Damodar valley of India
}

\author{
Saurabh Pal* \\ 26/A Suraksha Nagar, ICD Road, Ahirwan, Kanpur 208 007, India
}

Fossils of proterosuchians are known from the Early Triassic beds of many different countries like China, Russia, South Africa and India. Remains of the earliest described proterosuchian Ankistrodon indicus, are known from the Lower Triassic beds of the Panchet Formation of India. Later, the genus was renamed as Chasmatosaurus indicus. Chasmatosaurus is now considered as a junior synonym of Proterosuchus. The Early Triassic archosauromorph remains from India are based on rare and poorly preserved proterosuchian jawbones, few vertebrae and an ilium. This article reports the discovery of additional Proterosuchus fossil material, humerus and rediscovery of the cervical and caudal vertebrae from the Lower Triassic beds of the Panchet Formation, from the locality near Asansol district, West Bengal, India. Proterosuchus humerus has not been described before from India; hence this additional material along with axial materials that are a cervical vertebra and a caudal vertebra will add further information about this Early Triassic proterosuchidae of India.

Keywords: Cervical and caudal vertebrae, fossil remains, humerus, proterosuchian, Proterosuchus.

THE sedimentary strata of the Gondwana Supergroup are known from discrete basins in peninsular India. In the E-W-trending Damodar valley several discrete basins of the Gondwana Supergroup occur ${ }^{1,2}$. Among these, the Raniganj basin is well known for its vertebrate fossils of dicynodonts, cynodonts, amphibians, fishes and proterosuchian from the strata of the Panchet Formation ${ }^{3-5}$. Based on Lystrosaurus and another vertebrate fauna assemblage, the Panchet Formation is assigned Early Triassic in age ${ }^{3,6}$. Although the Panchet Formation is known for different species of dicynodonts and amphibians, Proterosuchus (Chasmatosaurus) indicus, a proterosuchian from the Lower Triassic horizon of India is known from few isolated and poorly preserved fossilized bones $^{3,4,7}$.

Remains of Ankistrodon indicus from the Panchet Formation, which was originally described by Huxley ${ }^{3}$ as a 'thecodont-saurian', was based on a fragmented

*e-mail: saurabhpal4u@gmail.com

jawbone bearing two hook-shaped teeth is the earliest described proterosuchian in the world ${ }^{8}$. Huene suggested that A. indicus belongs to the genus Chasmatosaurus 9 . Later, Satsangi ${ }^{4}$ discovered isolated lower jawbone and pelvis associated with fossils of Lystrosaurus and labyrinthodonts from the sandstone of the Panchet Formation. The jawbone described by Satsangi ${ }^{4}$ is similar to the Chasmatosaurus jawbone described by Huxley ${ }^{3}$, but more complete and better preserved, Satsangi ${ }^{4}$ considered those materials as Chasmatosaurus. Apart from the partial jaw of $A$. indicus, Huxley ${ }^{3}$ also described many vertebrae which he considered as remains of Dicynodon orientalis. Later von Huene ${ }^{9}$ suggested that these vertebrae belong to Chasmatosaurus ${ }^{9}$. Romer $^{10}$ amended Chasmatosaurus as an invalid genus and put all the species of Chasmatosaurus under an already established genus Proterosuchus.

Proterosuchian remains are known from Early Triassic beds of nearly every part of the world, including South Africa, China, Russia, Australia, Argentina, Germany and India $^{11}$. Fossil materials of Proterosuchus from India are known from very few materials which include part of jawbones, few fragmented axial materials and a pelvic bone, but so far no element of Proterosuchus limb bone has been reported or described. This article describes a proterosuchian humerus bone and two rediscovered vertebrae which are similar to the already described vertebrae of Proterosuchus by Huxley ${ }^{3}$.

\section{Systematic palaeontology}

Diapsida $^{12}$, Sauria ${ }^{13}$, Archosauromorpha ${ }^{14}$, Archosauriformes $^{15}$, Proterosuchidae ${ }^{16}$, Proterosuchus ${ }^{17}$.

\section{Referred specimens}

(i) PGRU/GL/M/VF-001 - Distal half of the left humerus. (ii) PGRU/GL/M/VF-002 - An anterior cervical vertebra. (iii) $\mathrm{PGRU} / \mathrm{GL} / \mathrm{M} / \mathrm{VF}-003-\mathrm{A}$ posterior caudal vertebra.

Here, PGRU represents Post Graduation College of the University of Ranchi, GL the Department of Geology and M, the Museum of the Department of Geology, University of Ranchi. 
Methodology: Apart from the three fossil materials mentioned above, various publications are referred here to understand the osteology of proterosuchians and archosaurs. Published diagrams and photographs along with their description were referred to for comparison with the discovered fossil materials described here.

Locality: Southern bank of River Damodar, Madhukunda (15 km southwest of Asansol), Paschim Bardhaman district, West Bengal.

Horizon and age: All the above-described fossil specimens were collected from the pebbly-yellow sandstone of the Panchet Formation of Early Triassic age ${ }^{18,19}$. Lithology which yielded these vertebrate fossils is the clay pelletrich, pebbly, micaceous and matrix-supported yellow sandstone which is well known for its vertebrate fossils which include temnospondyl, cynodont, dicynodont, and Proterosuchian $^{3,5-7}$.

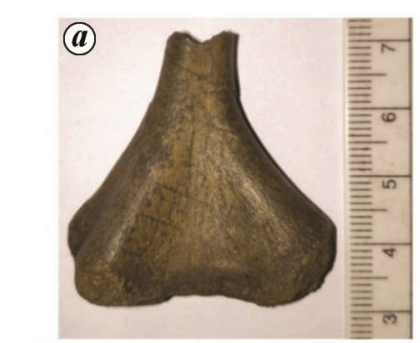

(c)

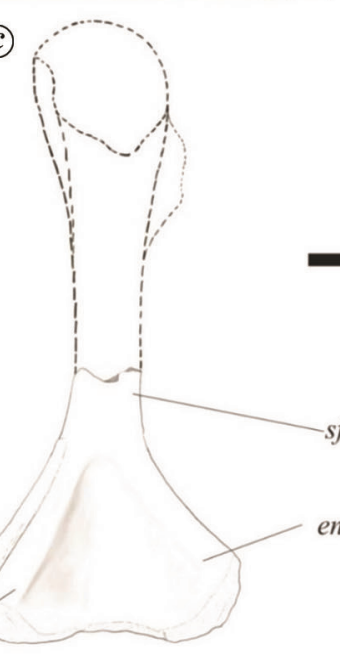

.

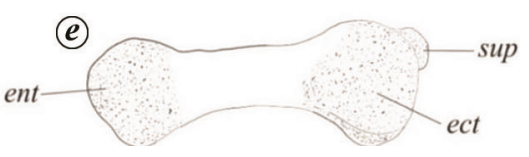

Figure 1. Proterosuchus - humerus from the Panchet Formation, India. (a-e) Distal half of the left humerus (PGRU/GL/M/VF-001). (a) and $(\boldsymbol{c})$ from posterior view; $(\boldsymbol{b})$ and $(\boldsymbol{d})$ from anterior view and $(\boldsymbol{e})$ from distal view. In $(\boldsymbol{c}$ and $\boldsymbol{d})$ reconstructed missing part of the humerus is represented as a dashed line by taking reference of the humerus (IVPP V2719) of Proterosuchidae Proterosuchus (Chasmatosaurus) yuani $^{20}$. Scale bar $=1 \mathrm{~cm}$. ect, Ectepicondyle; ent, Entepicondyle; sft, Shaft; sup, Supinator process.

\section{Description}

\section{Humerus (PGRU/GL/M/VF-001)}

Only the distal half of the left humerus is preserved (Figure 1). Entepicondyle and ectepicondyle are large and strongly developed; the supinator process is also well developed. The distal half of the humerus is broad compared to the part of the shaft preserved. The anterior distal fossa is well developed and covers a large area. The absence of entepicondylar and ectepicondylar foramen rules out the possibility of its cynodont origin. The cross-section of the shaft is square-shaped. The length of the preserved part is $3.6 \mathrm{~cm}$, width of the preserved shaft is $0.9 \mathrm{~cm}$ and width of the distal end of the humerus is $3.9 \mathrm{~cm}$. This specimen shows remarkable similarity to the humerus of Proterosuchus (Chasmatosaurus) yuani (IVPP V2719), from the Lystrosaurus bed of the Early Triassic from Sinkiang, China ${ }^{20}$.

\section{Anterior cervical vertebra (PGRU/GL/M/VF-002)}

In the single isolated cervical vertebra, one of the prezygapophyses and posterior part of the centrum are not preserved (Figure 2). The neural spine of the vertebra is flat and broad, where the dorsoventral height of the neural spine $(1.4 \mathrm{~cm})$ nearly equals its anteroposterior length $(1.5 \mathrm{~cm})$. Diapophysis and parapophysis are indistinguishable and present as a single facet low down near the anterior most margin of the centrum. Based on the position of the rib facet, the position of the vertebra is considered as anterior cervical. The anterior articular surface of the centrum is concave, but it is not possible to comment on the posterior articular surface of the centrum as the posterior end of the vertebra is not preserved. The specimen described here shows a close resemblance to the cervical vertebra of proterosuchians based on the description provided by Hughes ${ }^{21}$ and Ezcurra ${ }^{8}$.

\section{Posterior caudal vertebra (PGRU/GL/M/VF-003)}

A single isolated posterior caudal vertebra is completely preserved (Figure 3). The centrum is amphicoelous and elongated; the length $(1.3 \mathrm{~cm})$ to posterior height $(0.6 \mathrm{~cm})$ ratio is 2.17 . Rib facets are reduced and located towards the posterior end of the vertebra. Two parallel laminae run anteroposteriorly on the ventral surface of the centrum. The lateral surface is slightly concave longitudinally. The anterior and posterior articular surface of the centrum has a slightly elliptical shape with a dorsoventrally long axis. The posterior caudal vertebra described here resembles that of Proterosuchus ${ }^{20,22}$.

\section{Discussion and conclusion}

Materials described here belong to a species of Proterosuchus, based on common characteristics with other 
(a)
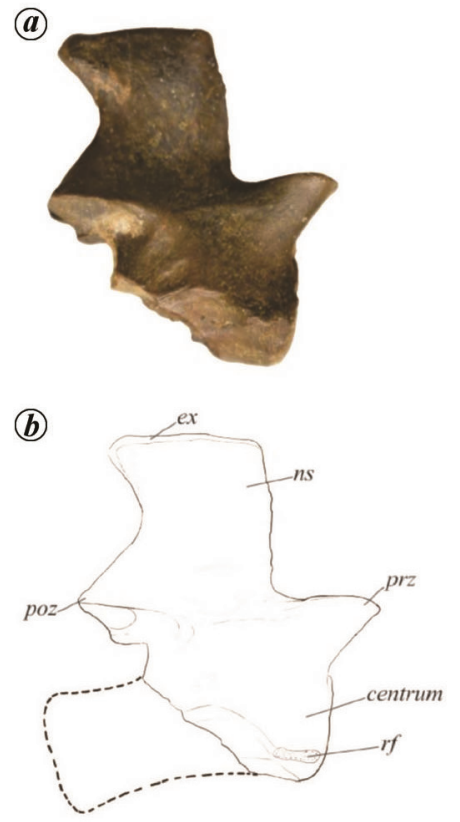

(c)
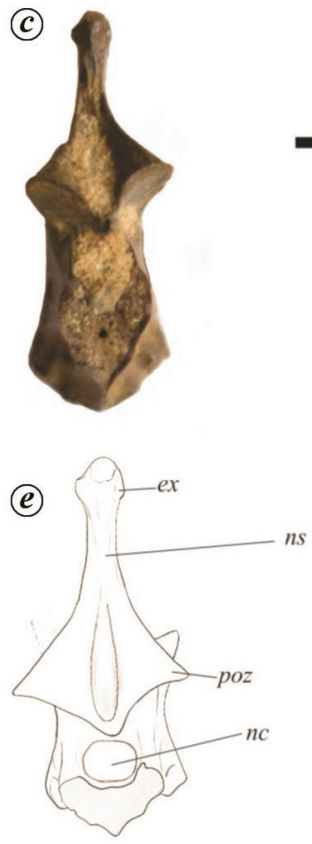
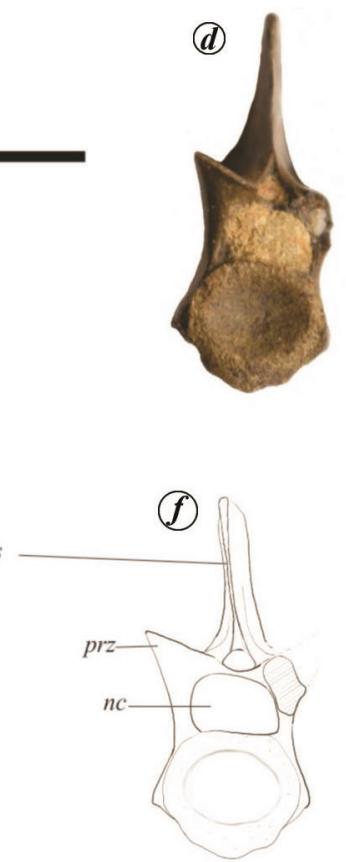

Figure 2. Proterosuchus - cervical vertebra from the Panchet Formation, India. Anterior cervical vertebra (PGRU/GL/M/VF-002). (a) and (b) from right lateral view; $(\boldsymbol{c})$ and $(\boldsymbol{e})$ from posterior view and $(\boldsymbol{d})$ and $(\boldsymbol{f})$ from anterior view. Scale bar $=1 \mathrm{~cm}$. ex, Expansion; nc, Neural canal; ns, Neural spine; poz, Postzygapophysis; prz, Prezygapophysis and rf, Rib facet.

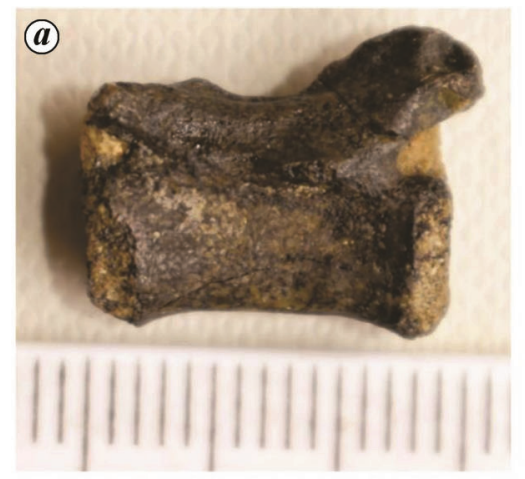

(c)

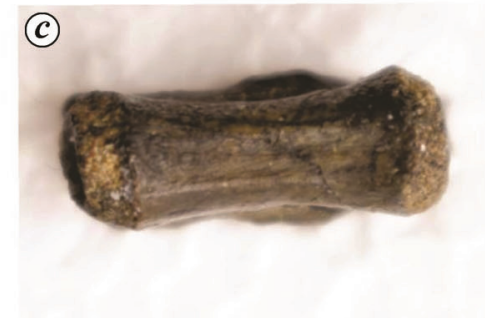

(b)

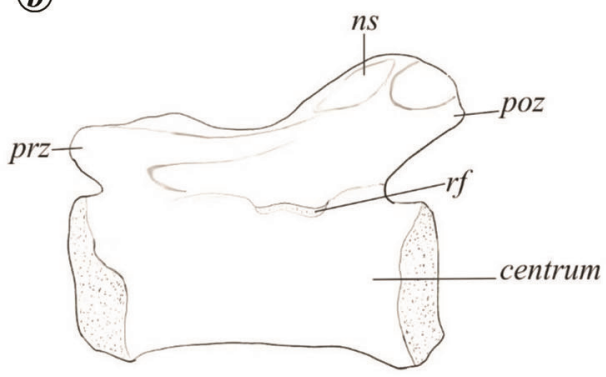

(d)

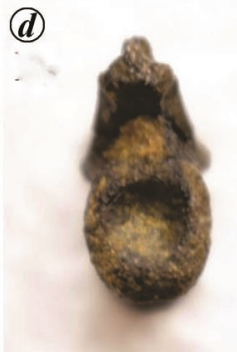

Figure 3. Proterosuchus - caudal vertebra from the Panchet Formation, India. Posterior caudal vertebra (PGRU/GL/M/VF-003). (a) and (b) from left lateral view; (c) from ventral view showing two ventral lamellae and $(\boldsymbol{d})$ from posterior view. Scale bar $=1 \mathrm{~cm}$. ns, Neural spine; poz, Postzygapophysis; prz, Prezygapophysis and rf, Rib facet.

overlapping Proterosuchus fossil materials discovered from the Early Triassic Lystrosaurus zone of the Karoo basin of South Africa ${ }^{21}$ and the Lystrosaurus bed of Sinkiang, China ${ }^{20}$. Species of this Proterosuchus must be considered as $P$. indicus, as it is the only species of this genus so far known from India. As the earlier described Proterosuchus fossils from India do not include any limb elements, hence the humerus bone described here increases the completeness of the skeletal material ${ }^{3,4}$. The addition in the records of Proterosuchus fossil remains 


\section{RESEARCH ARTICLES}

strengthens the idea of the Proterosuchus population in India during the Early Triassic. Further exploration and research are required to recover and study more vertebrate fossils from the Early Triassic beds of India, to increase the skeletal completeness of extinct species.

1. Chakraborty, C., Mandal, N. and Ghosh, S. K., Kinematics of the Gondwana basins of peninsular India. Tectonophysics, 2003, 377, 299-324.

2. Valdiya, K. S., Gondwana tectonics, inland sedimentation and life In The Making of India. Society of Earth Scientists Series, Springer, Cham, 2016; https://doi.org/10.1007/978-3-319-25029813.

3. Huxley, T. H., On a collection of vertebrate fossils from the Panchet rocks, Raniganj, Bengal. Palaeontol. Indica Ser., 1865, 3 , $1-24$.

4. Satsangi, P. P., A note on Chasmatosaurus from the Panchet Series of Raniganj Coal field, India. Curr. Sci., 1964, 33, 651652.

5. Bandyopadhyay, S., Gondwana vertebrate faunas of India. Proc. Indian Natl. Sci. Acad. Sect A, 1999, 65, 285-313.

6. Robinson, P. L., Some new vertebrate fossils from the Panchet Series of West Bengal. Nature, 1958, 182, 1722-1723.

7. Tripathi, C. and Satsangi, P. P., Lystrosaurus fauna from the Panchet Series of Raniganj Coalfield. Palaeontol. Indica (N.S.), 1963, 37, 1-53

8. Ezcurra, Martín D., The phylogenetic relationships of basal archosauromorphs, with an emphasis on the systematics of proterosuchian archosauriforms. Peer J., 2016, 4, e1778; doi:10.7717/ peerj. 1778 .

9. Huene F. von, Die fossilen Reptilien des südamerikanischen Gondwanaland es. Ergebnisse der Sauriergrabungen in Südbrasilien, 1928/1929. München: C.H. Becksche Verlagsbuchhandlung, München, 1942.

10. Romer, A. S., The Chañares (Argentina) Triassic reptile fauna. XVI. Thecodont classification. Breviora, 1972, 395, 1-24.

11. Nesbitt, S. J. et al., In Anatomy, Phylogeny and Palaeobiology of early Archosaurs and their Kin (eds Nesbitt, S. J., Desojo, J. B. and Irmis, R. B.), Geological Society of London, Special Publication, 2013, vol. 379, pp. 241-274
12. Osborn, H. F., The reptilian subclasses Diapsida and Synapsida and the early history of the Diaptosauria. Mem. Am. Mus. Nat. Hist., 1903, 1, 449-519.

13. Gauthier, J. A., A cladistic analysis of the higher categories of the Diapsida. Ph.D. thesis, University of California, Berkeley, USA, 1984, p. 564.

14. Huene, F. von, Die grossen Stämme der Tetrapoden in den geologischen Zeiten. Biol. Zentralblatt., 1946, 65, 268-275.

15. Gauthier, J. A., Kluge, A. G. and Rowe, T., Amniote phylogeny and the importance of fossils. Cladistics, 1988, 4, 105-209.

16. Huene, F. von, Die Dinosaurier der europäischen Triasformation mit Berücksichtigung der aussereuropäischen Vorkommnisse. Geol. Paläontol. Abhandl. Suppl., 1908, 1, 1-419.

17. Broom, R., On a new reptile (Proterosuchus fergusi) from the Karroo beds of Tarkastad, South Africa. Ann. South Afr. Mus., 1903, 4, 159-164.

18. Ghosh, S. C., Nandi, A., Ahmed, G. and Roy, D. K., Study of Permo-Triassic boundary of Gondwana sequence of Raniganj Basin, India. Proc. Vol. Gondwana Nine, 1994, 2, 179-194.

19. Pant, P. R. and Murty, B. V. S., Geological exploration of coal: the Indian scenario. Mem. Geol. Soc. India, 2004, 59, 310.

20. Young, C.-C., Additional remains of Chasmatosaurus yuani Young from Sinkiang, China. Vertebr. PalAsiatica, 1963, 7, 215 222 .

21. Hughes, B., The earliest archosaurian reptiles. South Afr. J. Sci., 1963, 59, 221-241.

22. Young, C.-C., On a new Chasmatosaurus from Sinkiang. Bull. Geol. Soc. China, 1936, 15, 291-311; doi:10.1111/j.17556724.1936.mp15003003.x.

ACKNOWLEDGEMENTS. I thank Dr Michael Benton (University of Bristol, UK) for help in identifying the fossil remains, and Dr Bijay Singh (Head, Department of Geology, University of Ranchi) for maintaining the fossil specimens in the museum of the Department of Geology, University of Ranchi. I also thank Mr Sudip Kumar Mahato (University of Ranchi) for help during the study.

Received 19 April 2020; revised accepted 27 March 2021

doi: $10.18520 / \mathrm{cs} / \mathrm{v} 120 / \mathrm{i} 11 / 1749-1752$ 